KULTURA

i

TERAPIA PRACA,,

\title{
CZYLI WYBRANE ZAGADNIENIA NOWEJ EKONOMII SPOŁECZNEJ
}

\section{IDEA NOWEJ EKONOMII SPOŁECZNEJ}

Zajmę się tu wybranymi aspektami ekonomii społecznej, zwanej także ekonomią solidarności, gospodarką społeczną lub przedsiębiorczością społeczną. Wraz z rozwojem sektora organizacji pozarządowych w ciągu ostatnich lat stała się ona znaczącym narzędziem stosowanym do walki z biedą i wykluczeniem społecznym. Problemy ekonomiczne i ich bolesne skutki społeczne okresu transformacji wymusiły konieczność poszukiwania dodatkowych możliwości rozwiązywania kwestii społecznych. Klasyczna formuła pomocy społecznej (zwanej niegdyś „opieką”), odwołująca się do redystrybucji, a nie produkcji, nie umożliwia osiągania celów społecznych z wykorzystaniem działalności gospodarczej. Oczywiście, pomysł na walkę z biedą z wykorzystaniem „terapii pracą”, czyli przy współudziale samych biednych, nie jest wyjściem uniwersalnym. Nie może być traktowany jako jedyne antidotum na biedę, zwłaszcza jeśli podjęcie pracy jest niemożliwe ze względu na wiek, chorobę, specyficzne warunki rodzinne. Najsłabszym członkom społeczeństwa instytucje państwowe muszą zapewniać godne warunki życia. Ekonomia społeczna ma wartość suplementarną: „, [...] oznacza generowanie alternatywnych rozwiązań, ale nie ustrojowej alternatywy. Nie jest pomyślana jako idea i droga odrzucenia rynku i państwa, ale jako ścieżka systemowej ewolucji" (Giza-Poleszczuk, Hausner 2008, s. 15).

Idea ekonomii społecznej, obejmująca zatrudnienie socjalne, opiera się na założeniach aktywnej polityki społecznej, a przede wszystkim dobrowolnej partycypacji społecznej i kierowania aktywnego wsparcia głównie do osób bezrobotnych zdolnych do pracy. Sądzę, że założenia te w dużej mierze wpisują się w koncepcję ojca Józefa Wrzesińskiego, prekursora nowego podejścia do ubó-

Adres do korespondencji: mdanecka@isppan.waw.pl 
stwa. Albowiem propagowane przezeń szacunek dla biednych, troska o ich godność i współpraca oparta na zaufaniu to wartości, które są także fundamentem ekonomii społecznej. Bez nich nie ma ona racji bytu. Praca $z$ biednymi i wykluczonymi z rynku pracy opiera się właśnie na tych wartościach. Sukces wymaga tu wysiłku, zaufania, silnej wiary, odwagi obu stron: uczestników, czyli beneficjentów, i kadry fachowców. Ta specyficzna forma pomocy zawiera w sobie, czego często nie dają tradycyjne formy pracy w ramach instytucji pomocy społecznej, misję opartą na współodpowiedzialności. Oznacza to, że osoby objęte pomocą same ustalają hierarchię własnych potrzeb społecznych, zawodowych, materialnych, a pracownicy pomagają wykreować możliwie najefektywniejsze drogi zaspokojenia tych potrzeb według indywidualnego planu rozwoju. Działania w ramach zatrudnienia socjalnego mają też inne zadanie, polegające na przywracaniu poczucia wartości ludziom, którzy w wyniku rozmaitych okoliczności życiowych utracili je we własnych oczach, ale także w ocenie innych, otoczenia społecznego, rodziny. Chodzi tu o wiarę we własne siły i bycie potrzebnym innym ludziom dzięki swej pracy. W ten sposób osoby wykluczone, jeśli tylko tego chcą, mają szansę nabrania pewności siebie i ulokowania swoich zdolności na rynku pracy. Współpraca tutaj to nie tylko wspólne ustalanie zasad, norm, drogi do osiągnięcia celu, praw i obowiązków obu stron, ale też wyzwalanie inicjatywy i uczestnictwo w tworzeniu konkretnych wspólnych przedsięwzięć, na przykład założenie spółdzielni socjalnej, wykonywanie prac zleconych, choćby we własnej pracowni krawieckiej, w kwiaciarni, kuchni. Dzięki temu uczestnicy zajęć identyfikują się z działalnością wspólną i traktują ją jako własną.

Nakreślony idealny wizerunek fundamentalnych wartości tworzących podstawę działania w ramach zatrudnienia socjalnego nie jest wolny od zagrożeń. Jak we wszystkich innych formach działania w pracy socjalnej może dochodzić do złych praktyk, konfliktów, mogą powstawać zawiedzione nadzieje, niespełnione oczekiwania, brak zaufania, przejawy braku szacunku i zwątpienia. Wtedy świat ludzi wykluczonych i świat instytucji, ich pracowników, którzy powinni być zaangażowani w pracę nad poprawą warunków życia osób biednych, tworzą opozycję nie do zaakceptowania, niezrozumiałą przez resztę społeczeństwa.

Na polu walki z wykluczeniem i biedą ekonomia społeczna ma do spełnienia kilka ważnych zadań. Można ich szukać na płaszczyźnie indywidualnej $\mathrm{w}$ ramach pracy $\mathrm{z}$ poszczególnymi osobami z wykorzystaniem metody reintegracji społecznej i zawodowej, a także na płaszczyźnie społecznej, gdy celem jest poprawa jakości kapitału społecznego i kondycji rynku pracy w wymiarze systemowym, a tradycyjne formy pracy socjalnej są wzbogacone dodatkowymi metodami inkluzji społecznej. Wykorzystując i uzupełniając rozważania Piotra Sałustowicza (2006, s. 13-35), można wyodrębnić następujące funkcje ekonomii społecznej:

1) edukacyjno-motywacyjna - pomnażanie i poprawa jakości kapitału społecznego z wykorzystaniem indywidualnej chęci działania; 
2) integracyjna - włączanie jednostek i grup społecznych w proces demokratyzacji życia publicznego, wzrost spójności społecznej;

3) zatrudnieniowa - tworzenie nowych miejsc pracy dla osób, które nie mają szans same odnaleźć własnego miejsca na rynku pracy;

4) szkoleniowa - proponowanie uwzględniających potrzeby rynku pracy usług w zakresie szkolenia zawodowego;

5) usługowa - dostarczanie usług socjalnych dla jednostek i zbiorowości, zwłaszcza tam, gdzie sektor prywatny i publiczny nie są w stanie zaspokoić potrzeb społecznych;

6) systemotwórcza - ekonomia społeczna ma być polem tworzenia się alternatywnego systemu ekonomicznego i społecznego;

7) demokratyzacyjna - wykorzystanie i wzmocnienie współpracy podmiotów należących do różnych sektorów władzy.

Chociaż korzenie idei ekonomii społecznej sięgają daleko w przeszłość i obecna jej formuła znacznie różni się od tzw. starej, to przyczyna wzrostu popularności jej założeń bywa podobna w różnych okresach historycznych. Najogólniej można powiedzieć, że ekonomia społeczna pojawia się wtedy, gdy powstają nowe oczekiwania społeczne co do działania państwa i gospodarki podyktowane koniecznością redefinicji ładu społeczno-gospodarczego. Gdy państwo opiekuńcze znajduje się w kryzysie, nie wypełnia swych „opiekuńczych" zobowiązań wobec obywateli, powstaje pytanie, dlaczego ludzie biedni zepchnięci na margines życia publicznego nie mogą, jeśli odczuwają taką potrzebę i determinację, tworzyć, działać, uczestniczyć w życiu społecznym. Wtedy jako odpowiedź na niezaspokojone potrzeby społeczne proponuje się zbiorowe formy gospodarowania (czy to $\mathrm{w}$ formie organizacji pozarządowych czy spółdzielni, instytucji zatrudnienia socjalnego). Warunkiem niezbędnym powstawania tego typu podmiotów jest potencjał społeczny i ekonomiczny, a więc ludzie gotowi przekładać cele społeczne ponad zysk ekonomiczny, budżet gotowy inwestować w sferę społeczną oraz uwarunkowania prawne zezwalające na legalne, swobodne działanie ${ }^{1}$.

Idea nowej ekonomii społecznej z misją społeczną jako wartością nadrzędną zawiera również, jak sama nazwa wskazuje, aspekt ekonomiczny. Przedsiębiorczość jest tu jednak jedynie środkiem do osiągania celów, a nie celem samym

1 Chodzi tu o cały zbiór swobód obywatelskich w państwie demokratycznym. Szczegółowe rozwiązania są zagwarantowane $\mathrm{w}$ następujących aktach prawnych: ustawa z 6 kwietnia $1984 \mathrm{r}$. O fundacjach z późniejszymi zmianami, ustawa Prawo o stowarzyszeniach z dnia 7 kwietnia $1989 \mathrm{r}$. z późniejszymi zmianami, ustawa Prawo spótdzielcze z 1982 r. z późniejszymi zmianami, ustawa z dnia 27 kwietnia 2006 r. O spótdzielniach socjalnych z późniejszymi zmianami, ustawa z 13 czerwca 2003 r. O zatrudnieniu socjalnym z późniejszymi zmianami, ustawa z dnia 27 sierpnia 1997 r. $O$ rehabilitacji zawodowej $i$ społecznej oraz zatrudnianiu osób niepetnosprawnych z późniejszymi zmianami, ustawa z dnia 22 maja 2003 r. O działalności ubezpieczeniowej z późniejszymi zmianami, ustawa z dnia 24 kwietnia 2003 r. O działalności pożytku publicznego i wolontariacie z późniejszymi zmianami oraz Rezolucja Parlamentu Europejskiego z dnia 19 lutego 2009 r. w sprawie gospodarki społecznej. 
w sobie - chociaż zysk ekonomiczny stanowi warunek działania i dalszego rozwoju. Obecnie w Polsce duże znaczenie mają środki z funduszy unijnych, które umiejętnie pozyskiwane i efektywnie wydatkowane mogą w znacznym stopniu przyczynić się do ograniczania biedy i zaniedbań rozwojowych $\mathrm{w}$ wielu regionach naszego kraju.

Działania ekonomii społecznej na rzecz ludzi ubogich, którzy nie radzą sobie z wymogami rynku pracy, polegają na przywracaniu im zdolności społecznych i kwalifikacji zawodowych - na odbudowaniu etosu pracy przez „terapię pracą", a tym samym pracę nad sobą i własnymi kompetencjami. Celem ostatecznym jest usamodzielnienie się na rynku pracy, tak aby człowiek pogrążony w ubóstwie i od lat bezrobotny mógł sam własną pracą zdobywać środki materialne do zaspokajania swoich potrzeb. Jest to więc propozycja wymagająca wysiłku i zaangażowania w proces reintegracyjny — oferowanie wędki, a nie ryby, jak mówi się w znanym porzekadle.

Podstawowym tradycyjnym środowiskiem działań gospodarki społecznej jest sektor organizacji pozarządowych — jako przestrzeń wyzwalania i realizacji oddolnych inicjatyw w środowisku lokalnym, ale nie tylko. Tu wyraźne jest rozróżnienie między starą a nową ekonomią społeczną. Obecnie realizacja celów społecznych odbywa się przy współpracy podmiotów należących do różnych sektorów władzy i własności, przy czym można mówić raczej o inkluzji wertykalnej niż horyzontalnej (Rymsza 2006). To współdziałanie wokół problemów społecznych i dialog władzy samorządowej, państwowej, organizacji i inicjatyw obywatelskich, w tym samych ludzi ubogich, wspólnot religijnych, sektora prywatnego, jest szczególnie ważne i może przyczynić się do efektywnego pomniejszenia skali ubóstwa.

Zakładając, że walka z ubóstwem będzie skuteczniejsza, gdy włączą się w nią różne podmioty, poszukuje się możliwości wykorzystania zintegrowanych działań na rzecz osób wykluczonych społecznie. Jako element ekonomii społecznej wypracowano zasady tzw. zatrudnienia socjalnego, które w polityce społecznej od kilku lat nieśmiało towarzyszy klasycznym rozwiązaniom. Dostarczają go instytucje działające na styku sektorów jako tzw. podmioty pogranicza (Rechulicz 2006) lub chyba lepiej można je określić jako instytucje „pośredniczące” między tradycyjnymi formami pomocy społecznej, instytucjami rynku pracy, organizacjami pozarządowymi (w tym także kościelnymi) oraz przejawami samoorganizacji i samopomocy osób dotkniętych wykluczeniem.

\section{ZATRUDNIENIE SOCJALNE - CELE I ZAŁOŻENIA}

Wiele lat temu Ralf Dahrendorf (1993, s. 237) uznał, że wyjście z marginesu sfery ekonomicznej zapewnia praca jako „bilet wstępu do świata zasobów". Dodawszy do tej obserwacji konstatację Zygmunta Baumana (1998), że długotrwale bezrobotni to nie rezerwowa armia pracy, ale rezerwowa armia pomocy społecznej, można uznać, że zatrudnienie socjalne stara się wręczyć 
ów „bilet wstępu” członkom „armii pomocy społecznej”. Jest to zadanie niełatwe, ale możliwe. Jak prezentuje się „armia” osób, które mogą korzystać $z$ tej specyficznej pomocy? Do kogo jest kierowana ta oferta? Skorzystać z niej mogą tylko osoby ubogie, w bardzo złej sytuacji materialnej i zawodowej, które na co dzień doświadczają deprywacji i silnie odczuwają przejawy dezintegracji społecznej. To klienci pomocy społecznej, urzędów pracy, poradni rodzinnych, ośrodków odwykowych, obozów dla uchodźców. Definicja zatrudnienia socjalnego ${ }^{2}$ mówi, że jest to forma pomocy osobom, które nie są $\mathrm{w}$ stanie własnym staraniem zapewnić sobie podstawowych potrzeb życiowych (brak jakichkolwiek źródeł utrzymania: dochodów z pracy, zasiłków, rent, emerytur, świadczeń socjalnych) oraz znalazły się w sytuacji uniemożliwiającej lub ograniczającej uczestnictwo w życiu zawodowym, społecznym i rodzinnym. Wymienia się następujące przyczyny i sytuacje życiowe, które uprawniają do korzystania z programu reintegracyjnego: bezdomność, uzależnienie od alkoholu, narkotyków, długotrwałe bezrobocie, choroba psychiczna, konflikt z prawem (dotyczy to osób, które po wyjściu $z$ więzienia nie są $\mathrm{w}$ stanie same wrócić do „normalnego życia”) oraz poszukiwanie przez uchodźców pomocy $\mathrm{w}$ funkcjonowaniu w polskim społeczeństwie.

Zatrudnienie socjalne może być realizowane na trzy sposoby:

1) $w$ formie uczestniczenia w zajęciach w Centrach Integracji Społecznej (CIS), które mogą być tworzone przez instytucje samorządowe (np. mogą działać przy ośrodku pomocy społecznej, urzędzie miasta) lub organizacje pozarządowe, w tym wyznaniowe (np. w Kielcach działa CIS stworzony przy Caritasie);

2) przez działalność w Klubach Integracji Społecznej (KIS), które są powoływane przez jednostkę samorządu terytorialnego lub organizacje pozarządowe; organizują i prowadzą działalność samopomocową w zakresie zatrudnienia, spraw socjalnych, porad prawnych; pomagają ludziom samoorganizować się w grupy, podejmować wspólne inicjatywy w zakresie aktywizacji zawodowej, w tym zmierzające do tworzenia własnych miejsc pracy;

3) przez zatrudnienie wspierane - jest to forma pomocy uczestnikom zajęć w CIS w podjęciu pracy u innego pracodawcy lub zatrudnienie $\mathrm{w}$ samym Centrum; może to być też praca w założonej przez uczestników spółdzielni socjalnej, która prowadzi wspólne przedsiębiorstwo w oparciu o osobistą pracę członków ${ }^{3}$.

Funkcjonowanie zatrudnienia socjalnego opiera się na swoistym kontrakcie, umowie między stronami - uczestnikami zajęć i personelem. Obie strony

2 Ustawa $O$ zatrudnieniu socjalnym, art. 1.

3 Art. 2 pkt 2 ustawy O spótdzielniach socjalnych z 2006 r. definiuje rolę podmiotu: „Spółdzielnia socjalna działa na rzecz: 1) społecznej reintegracji jej członków, przez co należy rozumieć działania mające na celu odbudowanie i podtrzymanie umiejętności uczestniczenia w życiu społeczności lokalnej i pełnienia ról społecznych w miejscu pracy, zamieszkania lub pobytu, 2) zawodowej reintegracji jej członków, przez co należy rozumieć działania mające na celu odbudowanie i podtrzymanie zdolności do samodzielnego świadczenia pracy na rynku pracy". 
podejmują wobec siebie zobowiązania w ramach wspólnie wypracowanych zasad, wartości, praw i obowiązków. W początkowej fazie wspólnie ustalany jest zakres wzajemnych relacji, potrzeb, które wymagają zdefiniowania, potem następuje poszukiwanie dróg ich zaspokojenia. Następnie podpisuje się tzw. indywidualny program zatrudnienia socjalnego, który - wypracowany w toku wielu rozmów z psychologami, pracownikami socjalnymi, doradcami zawodowymi, prawnikami - wskazuje wszystkie elementy, sfery i indywidualne problemy wymagające "naprawy”. Takie przygotowanie gruntu do pracy pozwala na realizację postawionego celu. Warunkiem jest uczestnictwo i zaangażowanie $\mathrm{w}$ pracę nad sobą $\mathrm{i}$ - o ile to możliwe - integracja $z$ innymi uczestnikami. W szczególnych przypadkach, gdy chodzi o problemy z uzależnieniem czy bezdomnością, wymagane jest udowodnienie determinacji w dążeniu do zmiany postaw i życiowych priorytetów: bezdomni muszą wykazać się uczestnictwem $\mathrm{w}$ indywidualnym programie wychodzenia $\mathrm{z}$ bezdomności, alkoholicy i narkomani powinni być po terapiach odwykowych. Uczestniczący w programie otrzymują symboliczną kwotę - świadczenie integracyjne w wysokości zasiłku dla bezrobotnych. Ich reintegracja społeczna obejmuje szereg szkoleń i kursów dotyczących współżycia społecznego i przywrócenia dobrej kondycji psychofizycznej. Są to na przykład wsparcie psychologiczne i terapie, kursy komunikacji interpersonalnej, tworzenie hierarchii celów życiowych i zachowań zgodnych z ustalonymi normami, poznawanie skutecznych sposobów motywowania działania, wzmacnianie poczucia własnej wartości, wzrost akceptacji siebie i innych, nabycie podstawowych umiejętności w radzeniu sobie ze stresem, nauka racjonalnego wydatkowania środków pieniężnych. Reintegracja zawodowa obejmuje nabywanie umiejętności zawodowych, przekwalifikowanie lub podwyższanie kwalifikacji zawodowych za pomocą programów edukacyjnych, szkoleń i kursów zawodowych, w których uczestniczy się z nadzieją na powrót do świata pracy i usamodzielnienia się w przyszłości na tzw. otwartym rynku pracy.

Czy to działa tak dobrze jak teoretycznie działać powinno? Pytałam o to uczestników zajęć CIS w 2007 r. - w zdecydowanej większości byli zadowoleni ${ }^{4}$. Tylko 5 z 210 respondentów uznało, że „CIS nie daje lepszych szans powrotu do normalnego życia niż inne instytucje pomocowe". Wśród zalet wymieniono: możliwość pracowania, przebywanie wśród ludzi, dobrą atmosferę i zaufanie do otoczenia, wsparcie finansowe i szansę na lepsze zarobki w przyszłości, możliwość nauki zawodu wybranego przez uczestnika, naukę odpowiedzialności, poznawanie technik walki ze stresem, wzrost motywacji do

\footnotetext{
4 Było to badanie audytoryjne z 210 uczestnikami zajęć wybranych CIS-ach, przeprowadzone w ramach grantu „Obszary wykluczenia w III Rzeczypospolitej. Przyczyny, przejawy, przeciwdziałanie”, zrealizowanego pod kierunkiem Marii Jarosz w Instytucie Studiów Politycznych PAN. Część wyników znalazła się w moim artykule pt. Ubodzy i bezrobotni, w: Maria Jarosz (red.), Wykluczeni. Wymiar spoteczny, materialny $i$ etniczny, ISP PAN, Warszawa 2008.
} 
działania. W innym badaniu ocena też była pozytywna ${ }^{5}$. Aż $87 \%$ uczestników oceniało, że dostaje „odpowiednią pomoc w powrocie do normalnego życia”. Wady CIS to „za małe zarobki”, jak określano świadczenie integracyjne (które ma raczej wartość symboliczną i nie powinno być traktowane jako „zarobek”) i „brak gwarancji pracy po skończeniu kursu”, co wskazuje na brak wyraźnego wyjaśnienia i akceptacji reguł gry - celem ma być przygotowanie do zatrudnienia, a nie sama praca. Duże nadzieje na znalezienie pracy po zakończeniu programu reintegracyjnego wyrażała większość uczestników zajęć. Charakterystyczna dla CIS-ów była dobra atmosfera i wysoka ocena zatrudnionej kadry przez podopiecznych, gdy tymczasem powszechnie znany jest antagonizm dwóch światów: klientów pomocy społecznej i urzędników. Tylko jeden na stu uczestników oceniał pracowników CIS jako ludzi obojętnych na krzywdę innych czy wręcz nieprzychylnych ${ }^{6}$. Byli oni doceniani za pomoc w sprawach życiowych i społecznych, a także jako doradcy zawodowi, fachowa pomoc w dążeniu do zdobycia zatrudnienia (dobre oceny wystawiało ok. 90\% respondentów). Jest to wynik satysfakcjonujący, chociaż pojawiały się też sygnały mówiące o złych stosunkach między uczestnikami zajęć a kadrą (o potrzebie poprawy stosunków panujących w Centrum mówił co dziesiąty respondent).

\section{PODMIOTY ZATRUDNIENIA SOCJALNEGO W PRAKTYCE}

Od momentu wejścia w życie ustawy $O$ zatrudnieniu socjalnym minęło już kilka lat, ale instytucja ta rozwinęła się na małą skalę, zwłaszcza jeśli weźmie się pod uwagę ogromne potrzeby w zakresie walki z ubóstwem. Wiedza o efektach działania, ocenach uczestników, warunkach pracy, możliwościach rozwoju i barierach funkcjonowania w sumie jest nieduża. Stosunkowo najłatwiej jest opisać Centra Integracji Społecznej - na podstawie sprawozdań wojewodów kierowanych do Ministerstwa Pracy i Polityki Społecznej. Wiedza o Klubach Integracji Społecznej jest bardzo ograniczona, gdyż nie ma podstawy prawnej do monitorowania ich działalności przez szczebel ministerialny. Podobnie jest ze spółdzielniami socjalnymi ${ }^{7}$. Chociaż coraz częściej spółdzielnie socjalne

5 Badanie pt. „Monitoring ustawy o zatrudnieniu socjalnym”, prowadzone było przez Pracownię Badań Organizacji Non-Profit ISP PAN na zlecenie MPiPS wiosną 2007 r., pozwoliło między innymi uzyskać oceny CIS, wystawiane przez uczestników (217 osób) i kadrę pracowniczą (19 jednostek). Więcej zob. w raporcie: E. Leś (red.), „Monitoring ustawy z dnia 13 czerwca 2003 r. o zatrudnieniu socjalnym. Badanie efektów reintegracji społecznej i zawodowej" (http://www.gospodarkaspoleczna.pl/index.php/badaniaarch).

${ }^{6}$ Zob. tamże.

7 Koordynacją KIS zajmują się regionalne ośrodki polityki społecznej podległe urzędom marszałkowskim. Diagnoza skali zjawiska, efektywności działań i kondycji Klubów wymagałaby pogłębionych badań na tym poziomie. Podstawowe dane można znaleźć w Krajowym Rejestrze Sądowym (wyszukiwarka odnalazła zaledwie 8 jednostek, choć dane z niektórych województw mówią o kilkunastu podmiotach tego typu). Obecnie przez MPiPS przygotowywane jest pierwsze duże badanie Klubów w całej Polsce, obejmujące uczestników i kadrę zawodową. Z kolei spółdzielnie jako orga- 
włączane są do badań i analiz rynku pracy i wykluczenia społecznego, brakuje aktualnych, kompleksowych ogólnopolskich danych diagnostycznych na ich temat. Dostępne informacje mają najczęściej formę regionalnych analiz prowadzonych na potrzeby projektów unijnego Programu Operacyjnego Kapitał Ludzki.

Dostępne dane wskazują, że dynamika rozwoju Centrów Integracji Społecznej jest niespodziewanie słaba. Pocieszenie może stanowić fakt, że ich liczba $z$ roku na rok rośnie (wykres 1 ).

Wykres 1

Liczba Centrów Integracji Społecznej (stan na koniec roku)

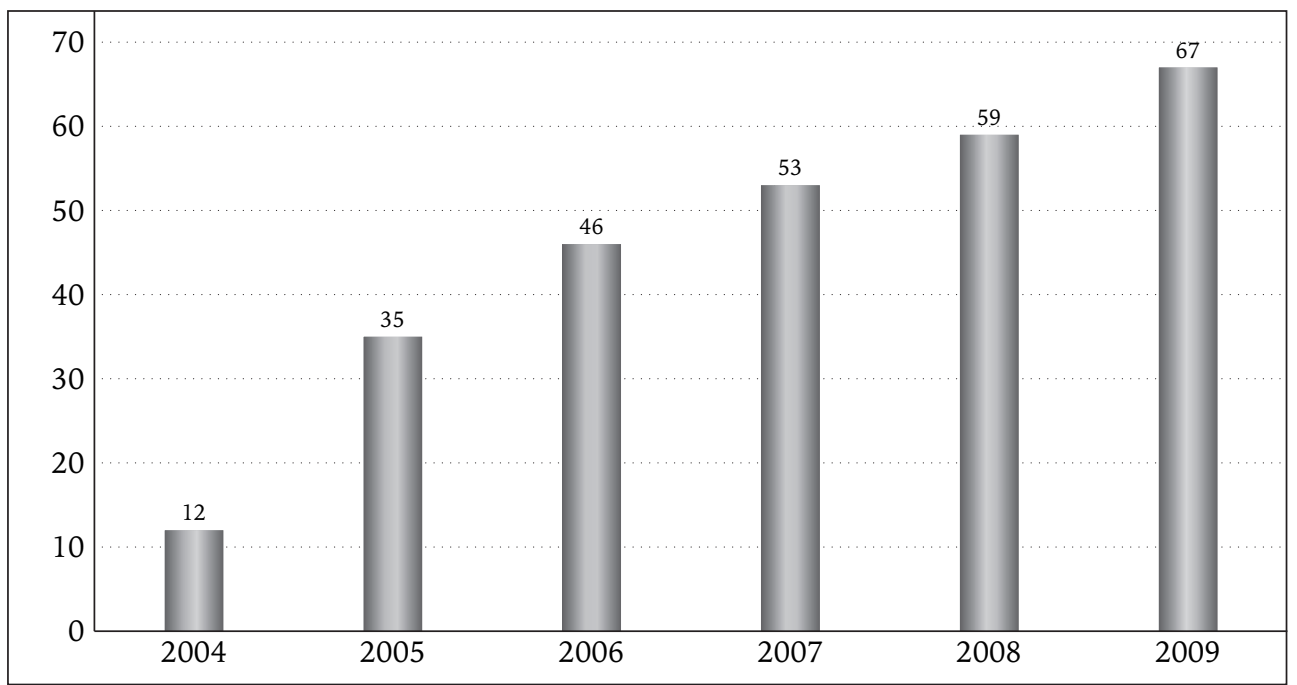

Źródło: opracowanie własne na podstawie danych MPiPS oraz Kaźmierczak 2005, s. 95.

Dane wskazują na nierównomierne rozmieszczenie CIS-ów w poszczególnych województwach. W 2008 r. liderem pod tym względem było województwo pomorskie, w którym funkcjonowało 9 takich instytucji. W województwie wielkopolskim było 8 , w mazowieckim 6 , w zachodniopomorskim -5 , po 4 w województwie śląskim i świętokrzyskim, w lubuskim, opolskim i warmińsko-mazurskim po 3 jednostki, w pozostałych po 2, w świętokrzyskim i podkarpackim istniały pojedyncze CIS-y. Trudno znaleźć przyczyny takiego dużego zróżnicowania przestrzennego. Niewątpliwie poza aspektami instytucjonalno-prawnymi oraz potencjałem organizacyjnym i finansowym powodów należy

nizacje pozarządowe można odnaleźć w bazie www.ngo.pl, gdzie wyszukano 250 jednostek z nazwą „spółdzielnia socjalna”. W roku 2007 było ich 140. Z danych ministerialnych z tego roku wynika między innymi, że tworzone były najczęściej przez pięcio-dziesięcioosobowe grupki bez fachowego przygotowania, co znaczyłoby, że tylko $10 \%$ założycieli spółdzielni ukończyło zajęcia w CIS. 
szukać w zróżnicowaniu zainteresowania i przedsiębiorczości społeczności lokalnych. Jeśli zapoznamy się z mapą terytorialnego rozkładu wskaźnika stopy bezrobocia długotrwałego, to nasuwa się pytanie, dlaczego ekonomia społeczna i zatrudnienie socjalne nie są bardziej wykorzystywane do walki z tym nieszczęściem? Czy winić za to niedoskonałości i małą efektywność tego podejścia, czy brak wiedzy i dobrych przykładów, a może brak zainteresowania ze strony osób wykluczonych?

Warto przyjrzeć się adresatom zatrudnienia socjalnego. Ile jest takich osób i kim są ubodzy, żyjący w poczuciu dezintegracji, którzy zdecydowali się skorzystać z tej formy pomocy? Zważywszy na fakt, że ludzi dotkniętych wymienionymi wyżej problemami i dysfunkcjami w Polsce są setki tysięcy, jako grupa bardzo mała mogą oni być traktowani jako swoista elita. W całej Polsce w 2009 r. było ich 5951 osób, w roku 2008 - 5030, a rok wcześniej 5230 osób). Niestety, osób, które kończą zajęcia, jest zdecydowanie mniej; w 2009 r. było ich 2765, w 2008 r. - 2553, a w 2007 r. - 2447. Nasuwa się pytanie, dlaczego ludzie otrzymując szansę wydostania się z biedy i decydując się na podjęcie pewnego wysiłku, nie kończą zajęć? Pytaliśmy o to w badaniu $z$ roku $2007^{8}$. Tak jak można było przypuszczać - tylko 8,4\% uczestników odchodziło z zajęć $z$ powodów niezależnych, jak na przykład choroba, $34 \%$ wcześniej uzyskiwało zatrudnienie, reszta była usuwana z powodu łamania regulaminu i zasad uczestnictwa (zbyt dużo nieobecności, nietrzeźwość na zajęciach, podejmowanie pracy „na czarno”). Na czele niechlubnej listy dezerterów stali wówczas narkomani, byli więźniowie oraz bezdomni. To im było najtrudniej dotrwać do końca zajęć.

Od początku uczestnikami zajęć oferowanych przez CIS-y są przede wszystkim osoby długotrwale bezrobotne. W roku 2009 stanowiły one $38 \%$ wszystkich uczestników (w 2008 r. - 45,4\%, w 2007 r. - 46,5\%). Na kolejnym miejscu znalazły się osoby zaliczane do takich grup ryzyka zagrożenia wykluczeniem społecznym jak: zwalniani z zakładów karnych - 7\% (2008 - 4,2\%, $2007-3,7 \%)$, uzależnieni od alkoholu $-5,7 \%(2008-6,7 \%, 2007-5,9 \%)$, bezdomni - 4,2\% (2008 - 5,2\%, $2007-5,4 \%)$. Pojedyncze przypadki stanowią osoby uzależnione od narkotyków i chore psychicznie. Dotychczas do żadnego CIS-u nie zgłosił się uchodźca.

Zdecydowanie częściej na udział w zajęciach decydują się mężczyźni: wskaźnik udziału kobiet w zajęciach reintegracji społecznej i zawodowej w 2009 r. wynosił 33,2\%. Mniej więcej na tym poziomie utrzymuje się od kilku lat. Spadła mobilizacja wśród kobiet, ponieważ w 2009 r. tylko 36,9\% z nich ukończyło zajęcia, a w 2008 r. absolwentek było aż 54,7\%. Wyraźnie widać duże zróż-

\footnotetext{
${ }^{8}$ Badanie „Monitoring ustawy o zatrudnieniu socjalnym”. Przytoczone w tym miejscu odpowiedzi pochodzą od pracowników. Niestety, nie mieliśmy możliwości wysłuchania ocen osób, które odeszły z CIS-ów. Ze względu na znaczny wzrost liczby podmiotów od $2007 \mathrm{r}$. oraz nowelizację ustawy w 2010 r. warto byłoby przeprowadzić kolejną edycję monitoringu.
} 
nicowanie partycypacji kobiet w poszczególnych województwach: w 2009 r. udział kobiet był największy w lubuskim i podlaskim (ok. 70\% uczestników to kobiety), najmniejszy - w śląskim (29\%). Wskaźnik udziału kobiet pozytywnie kończących zajęcia był najwyższy i najniższy odpowiednio w tych samych województwach ${ }^{9}$.

Autorzy koncepcji zatrudnienia socjalnego wskazali wiele usług psychologicznych, społecznych i zawodowych, które powinny ułatwić wychodzenie z wykluczenia społecznego. W tabeli 1 przedstawiono wskaźnik, który określa udział osób kończących dane zajęcia wśród tych, którzy zostali na nie skierowani.

Tabela 1

Wskaźnik udziału w zajęciach w latach 2007-2009 (w \%)

\begin{tabular}{|l|c|c|c|}
\hline \multicolumn{1}{|c|}{ Rodzaj zajęć } & 2007 & 2008 & 2009 \\
\hline Szkolenia zawodowe & 48,1 & 55,0 & 53,9 \\
Praktyki i staże zawodowe & 23,9 & 20,6 & 51,9 \\
Pomoc w pozyskaniu oferty pracy & 49,7 & 55,5 & 50,1 \\
Kurs prowadzenia samodzielnej działalności gospodarczej lub spół- & & & \\
$\quad$ dzielni socjalnej & 28,5 & 41,5 & 49,3 \\
Inne działania z zakresu reintegracji społecznej (np. spotkania z lo- & & & \\
$\quad$ kalnymi pracodawcami) & 44,6 & 44,3 & 49,9 \\
Terapia psychologiczna i pomoc terapeutyczna & 32,5 & 29,7 & 46,3 \\
Uczestnictwo w grupach samopomocowych i grupach wsparcia & 27,2 & 25,8 & 46,9 \\
Indywidualne konsultacje z psychologiem lub terapeutą & 42,3 & 45,9 & 50,2 \\
Grupy edukacyjne (podnoszenie poziomu wykształcenia) & 38,8 & 36,8 & 44,8 \\
\hline
\end{tabular}

Źródło: Informacja o działalności Centrów Integracji Społecznej w 2009 r., MPiPS, 2010.

Mimo że widoczny jest wzrost wskaźnika udziału w większości zajęć, niepokoi fakt znacznego braku konsekwencji i mała liczba absolwentów. Powraca pytanie o przyczyny tego stanu rzeczy. Czy leżą one po stronie organizatorów czy uczestników? Czy zajęcia są nieatrakcyjne, nieprzydatne, nie odpowiadają na faktyczne potrzeby osób objętych wsparciem, może wymagania są zbyt wygórowane? W tym miejscu przytoczę opinię z Monitoringu z 2007 r.: pytani o ocenę zajęć uczestnicy najczęściej wyrażali się o nich pozytywnie (80$-90 \%$ dobrych ocen). Wskazywali, że są one dobrze dopasowane do potrzeb, można uczestniczyć $\mathrm{w}$ tworzeniu planu rozwoju, są pomocne $\mathrm{w}$ procesie powrotu na rynek pracy. Można więc przypuszczać, że ci, którym program wy-

9 Z badania „Obszary wykluczenia w III Rzeczypospolitej” dowiedzieliśmy się ponadto, że: uczestnicy zajęć w CIS to osoby w wieku od 21 do 62 lat (średnia wieku 47 lat). Najczęściej są to osoby słabo wykształcone: $43 \%$ ma wykształcenie podstawowe, $39 \%$ ukończyło szkoły zasadnicze zawodowe, $14 \%$ - wykształcenie średnie, $4 \%$ to absolwenci szkół wyższych. Ponad połowa respondentów (61\%) miała wyuczony zawód. Najczęściej wymieniane to: krawiec, ślusarz, tokarz, rolnik, sprzedawca, kucharz, spawacz, mechanik. Prawie wszyscy badani mieli doświadczenie zawodowe. Wśród nich $40 \%$ osób przepracowało ponad dziesięć lat. 
chodzenia $z$ wykluczenia $z$ jakichś przyczyn nie odpowiadał, sami rezygnowali przed zakończeniem kursów. $\mathrm{Z}$ tego punktu widzenia ocena działań CIS-ów nie jest już taka dobra, zwłaszcza że wskaźnik zakończenia zajęć wydaje się w tym przypadku miarą cenniejszą niż samo uczestnictwo. W 2009 r. wynosił on $46,4 \%$, a w 2008 r. - 50,7\% w skali ogólnopolskiej. Oznacza to, że niespełna połowa uczestników kończy oferowane kursy. Wskaźniki dla poszczególnych województw świadczą o ogromnym zróżnicowaniu sytuacji w regionach i w ciągu kolejnych trzech lat. Zdecydowanie wzrosła efektywność pracy w CIS-ach w województwach dolnośląskim, podlaskim, pomorskim i zachodniopomorskim, a niepokojący spadek widać w Wielkopolsce, na Mazowszu, w województwie świętokrzyskim (zob. wykres 2).

Wykres 2

Wskaźnik ukończenia zajęć w CIS w poszczególnych województwach w latach 2007-2009 (w \%)

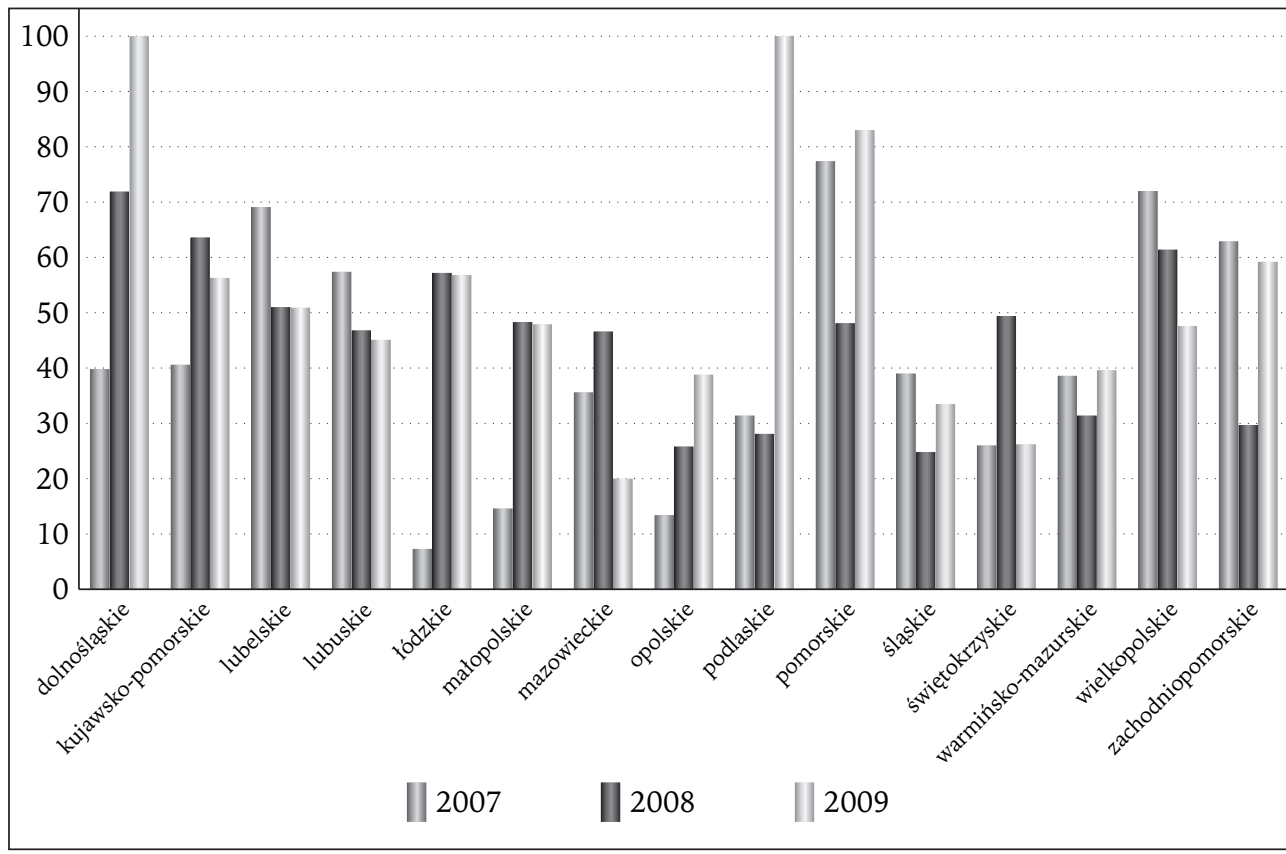

Uwaga: na wykresie nie uwzględniono woj. podkarpackiego, ponieważ pierwszy CIS powstał tam dopiero w 2009 r. i brak jest danych na temat jego uczestników.

Źródło: opracowanie własne na podstawie danych MPiPS.

Ostateczny sukces uczestnictwa w programach reintegracyjnych to powrót do „normalnego życia” i ekonomiczne usamodzielnienie, czyli zdobycie pracy na tzw. otwartym rynku pracy. I tu pojawia się drugi, obok niskiej efektywności zakończenia zajęć, zły wynik. Spośród 2765 osób, które ukończyły zajęcia w 2009 r., usamodzielniło się pod względem ekonomicznym, czyli roz- 
poczęło pracę zarobkową zaledwie 697 osób $(25,2 \%)$. Większość z tej grupy (62\%) znalazła zatrudnienie u pracodawców na tzw. otwartym rynku pracy, bez konieczności zastosowania dodatkowego instrumentu w postaci „zatrudnienia wspieranego", którą to metodę zastosowano wobec 149 osób (21,3\%). Pracę w samym CIS znalazło 59 osób (8,5\%). Najmniejszą grupą, 32-osobową $(4,6 \%)$, byli ci, którzy odważyli się podjąć własną działalność gospodarczą lub założyli spółdzielnię socjalną ${ }^{10}$. Porównajmy to z oczekiwaniami osób uczestniczących w zajęciach $\mathrm{w}$ roku 2007. Niepokój budził wówczas fakt, że duża grupa osób plany i marzenia na temat przyszłej pracy wiązała z CIS i tym samym wykazywała dużo obaw przed usamodzielnieniem się na tzw. otwartym rynku pracy: $38 \%$ deklarowało chęć zatrudnienia w placówce CIS lub u pracodawcy związanego z CIS. Zaledwie $10 \%$ respondentów rozważało założenie spółdzielni socjalnej. Jak widać strach przed tzw. normalnym zatrudnieniem został przezwyciężony, ale spółdzielnie socjalne popularności nie zyskały.

Kto płaci za zatrudnienie socjalne?

Charakterystyczną cechą podmiotów ekonomii społecznej jest zasilanie budżetu z różnych źródeł: „[...] wykazują one umiejętność pozyskiwania środków na rynku komercyjnym (ze sprzedaży dóbr i usług, kredytów, pożyczek), z zasobów nierynkowych (dotacje publiczne i darowizny osób prywatnych) oraz z zasobów niepieniężnych (praca wolontariuszy)" (Królikowska 2005, s. 73). Omawiany tu szczególny typ podmiotów, określonych wcześniej jako „pośredniczące" (między sferą samorządową a sferą organizacji pozarządowych i prywatnych), wyróżnia się tym, że podstawowe znaczenie ma finansowanie przez środki publiczne: gminne, wojewódzkie, ale nie tylko, ponieważ mogą to być także pieniądze prywatne - własne lub darowizny oraz dotacje pochodzące $z$ funduszy europejskich. Na przychody CIS-ów ${ }^{11}$, z roku na rok coraz większe, składają się, poza środkami finansowymi pochodzącymi z budżetów gmin, budżetów województw, środki z Funduszu Pracy, PFRON-u, własnej działalności i z tzw. innych źródeł, które obejmują środki z Europejskiego Funduszu Społecznego, darowizny, zbiórki itp. W ciągu trzech lat podstawowe źródło utrzymania uległo całkowitej zmianie. W roku 2007 były to głównie środki z EFS (83\%), a z gmin i województw otrzymywano zaledwie $12 \%$, rok później środki z EFS (27\%) były wspierane przez Fundusz Pracy (27\%) oraz przez budżety gmin (21\%). W roku 2009 zaś podstawowym źródłem stały się budżety gmin $(32 \%)$, a następnie „inne” przychody $(25,4 \%)$. Znaczny udział miały te $\dot{z}$

10 W 2008 r. wynik był nieco lepszy - efektywność usamodzielnienia się wynosiła $28 \%$. Podobnie jak w 2009 r. częstsze było zatrudnienie bez wsparcia (72,3\%), na zasadach zatrudnienia wspieranego - 14,2\%, w CIS znalazło pracę 7,4\% spośród usamodzielnionych, a na własną działalność odważyło się $3,2 \%$.

$11 \mathrm{~W} 2009 \mathrm{r}$. przychody wynosiły $32 \mathrm{mln}$, co oznaczało przeciętny przychód roczny na jedno centrum w wysokości 478,7 tys. złotych. Dla porównania w 2008 r. przychody centrów wyniosły ogółem 19,2 mln złotych (w 2007 r. zaledwie 1,2 mln), a przychód na jedno Centrum Integracji Społecznej 287 tys. 
środki pochodzące z Funduszu Pracy (22\%). Najniższy udział, jak i w latach poprzednich, miał Państwowy Fundusz Rehabilitacji Osób Niepełnosprawnych (marginalna kwota 62,3 tys.).

Budżety CIS-ów zasilane są także pieniędzmi z własnej działalności gospodarczej: wytwórczej, handlowej oraz usługowej. Najczęściej źródłem zysku są produkty wytwarzane w ramach praktycznej nauki zawodu. W 2009 r. własna działalność pozwoliła uzyskać w skali kraju przychody w wysokości 4,7 mln złotych, co stanowiło 14,6\% ogólnej kwoty przychodów (w 2008 r. było to $23 \%$, ale kwoty były dużo niższe). W 2007 r. własne dochody stanowiły jedynie $0,47 \%$ ! Odpłatna działalność CIS-ów najczęściej była prowadzona w formie usług porządkowych, prac remontowo-budowlanych, pracowni krawieckich, gastronomicznych i usług pielęgnacji zieleni miejskiej. Niektóre centra prowadziły działalność wytwórczą (np. produkcja mebli), transportową, opiekuńczą, kurierską, magazynową, kuśnierską, a nawet szkoleniową. Nabywcami usług CIS były przede wszystkim władze samorządowe oraz podległe im instytucje, czyli przedsiębiorstwa komunalne, rzadziej — indywidualni odbiorcy, spółdzielnie oraz firmy komercyjne.

\section{O NIEKTÓRYCH WĄTPLIWOŚCIACH}

Przedstawiona ocena działania i efektów Centrów Integracji Społecznej nie jest jednoznaczna. Sama idea tych instytucji, $z$ ich podmiotowym, partnerskim podejściem do podopiecznych, jest słuszna i pożądana. Należy jednak uznać, że pozostają one wciąż w fazie formowania się - poszukiwania nowych sposobów i warunków działania. Do tej pory powstało ich niewiele i działaniem swym obejmują małą, jak na polskie potrzeby, grupę osób dotkniętych biedą i wykluczeniem społecznym. Warto zwrócić uwagę na duże zróżnicowanie regionalne liczby CIS-ów oraz różną efektywność ich działania. Najogólniej można powiedzieć, że rozwój zatrudnienia socjalnego, mimo że jest ono formą trudną do realizacji, o czym może świadczyć mała skuteczność, wymagającą zaangażowania, wysiłku i odpowiedzialności wszystkich uczestników, jest potrzebny. Pełni rolę suplementarnego narzędzia walki z biedą i wykluczeniem społecznym ze względu na brak dostępu do rynku pracy.

Zaniepokojenie budzi fakt, że bardzo mała jest grupa osób, które po odbyciu zajęć osiągają zamierzony cel, czyli usamodzielniają się ekonomicznie i jak same mówią — „wracają do normalnego życia”. Interesujący jest w tym kontekście nadspodziewanie dobry obraz całego przedsięwzięcia $\mathrm{w}$ opiniach uczestników. Wydaje się zatem, że rola integracyjna jest spełniana należycie, przynajmniej w początkowej fazie. Doświadczenia instytucji zatrudnienia socjalnego wskazują jednak, że w środowisku lokalnym współistnieje kilka grup osób ubogich. Jedną stanowią osoby, które uczestniczą w zajęciach, lub już je ukończyły, i starają się otrzymać wspomniany „bilet do świata zasobów”, na drugą składają się ci, którzy mimo prób podjęcia współpracy z różnych 
przyczyn nie ukończyli kursu, trzecia - to wszyscy pozostali, którzy nie mieli możliwości lub nie byli zainteresowani tą formą działania, czwarta - ci, którzy po prostu nie chcą pomocy. Zatrudnienie socjalne może być traktowane jak sito, które określa, kto jest, a kto nie jest „wykluczony”, kto przy wsparciu ma szansę wydostania się z marginesu, a kto de facto zamierza pozostać klientem pomocy społecznej.

Jednak powstaje tu pułapka - zagrożenie niepożądanymi następstwami działania instytucji zatrudnienia socjalnego. Może ono stać się źródłem podziału. Uczestnictwo w zajęciach może spowodować w środowisku lokalnym stygmatyzację biednych. Także ci, którzy nie uczestniczą w zajęciach, mogą być napiętnowani i to zarówno przez środowisko pracowników socjalnych, jak i przez samych uczestników, którzy z własnego punktu widzenia surowej ocenie mogą poddawać bierność i brak woli walki dostrzegalne u innych biednych. Jedna z uczestniczek zajęć oceniła: „moja sytuacja jest zła, ale chcę wrócić do pracy i dlatego wolę tu przychodzić, uczyć się czegoś niż siedzieć $\mathrm{w}$ domu i czekać na zbawienie".

Według opinii kierowników CIS, ujawniły się dwa sposoby radzenia sobie z biedą i brakiem pracy. Jedni nauczyli się żyć bez pracy, korzystając z pomocy społecznej. „Funkcjonowanie w tak zwanej biedzie jest dla nich wygodne. To jest grupa, która się świetnie zna, wymieniają się informacjami co gdzie można zgarnać itd., i to ich uzależnia jak gra hazardowa. Ale to jest margines, z którego już nic nie będzie i tymi ludźmi pomoc społeczna w ogóle nie powinna się zajmować!". Druga grupa to osoby, które wstydzą się swojej biedy i chcą wyjść $z$ wykluczenia. „Z reguły nie sięgają one po świadczenia wypłacane w ramach pomocy społecznej lub korzystają z nich w ograniczonym zakresie - starając się radzić sobie we własnym zakresie pracując dorywczo, często na "czarno", albo przychodzą do nas i my staramy się wyprowadzić ich na prostą. Dla tych ludzi warto pracować" (Danecka 2008, s. 125).

Sądzę, że w takich sytuacjach najistotniejsze jest pytanie o uwarunkowania, głęboka analiza przyczyn, motywacji określonego działania lub jego braku. Na podstawie uzyskanych wiadomości powinna być podjęta próba ustalenia priorytetów życiowych osób dotkniętych ubóstwem na różnych etapach życia, hierarchii potrzeb i sposobów ich zaspokajania odpowiadających zasadom współżycia międzyludzkiego z poszanowaniem prawa do wolnego wyboru i godności osobistej. Należy występować w obronie tych najsłabszych, tak aby funkcja integrująca nie ustąpiła mechanizmom polaryzacji i naznaczenia. $\mathrm{Z}$ pewnością ani zatrudnienie socjalne, ani inne możliwości ekonomii społecznej nie zdołają rozwiązywać problemów bezrobocia i dezintegracji społecznej wszystkich grup defaworyzowanych na rynku pracy lub wręcz trwale $z$ niego wykluczonych. Nie można też zakładać wyeliminowania tradycyjnej pomocy społecznej, zwłaszcza wobec osób starszych, chorych, trwale niezdolnych do pracy. Nie można także ulegać przeświadczeniu, że wszyscy życzą sobie instytucjonalnej pomocy. Godne traktowanie ubogich musi polegać też na szanowaniu prawa do 
wyboru i wolności, bez wydawania fałszywych ocen, o ile działanie jest zgodne z obowiązującym prawem i normami życia społecznego.

W kontekście integracyjnej roli zatrudnienia socjalnego najtrudniej zgodzić się z jego funkcją systemotwórczą, która polega na tym, że ekonomia społeczna ma być miejscem tworzenia się alternatywnego systemu ekonomicznego i społecznego. Nadrzędnym celem działań jest bowiem wyjście z „systemu”, jaki tworzą instytucje pomocowe, i usamodzielnienie się na otwartym rynku pracy. Nawet w przypadku zatrudnienia wspieranego i spółdzielni socjalnych określone są ramy czasowe wyznaczające długość trwania wsparcia. Można mówić o „alternatywnych formach ekonomicznych i społecznych" w trakcie wsparcia, ale nie powinno się tworzyć swoistych gett, w których zagrożeniem może być na przykład zbyt duże zatrudnienie byłych uczestników w Centrach Integracji Społecznej. Chyba że systemem będzie w tym przypadku zbiór instytucji tworzonych w ramach zatrudnienia socjalnego, których „systemowośc” będzie służyła ponadregionalnej wymianie doświadczeń i promowaniu dobrych praktyk. W tym widzę ogromne pole do dialogu społecznego, współpracy instytucji należących do różnych sektorów władzy, podmiotów gospodarczych, inicjatyw obywatelskich, rozwoju edukacji, także badaczy życia społecznego.

\section{BIBLIOGRAFIA}

Bauman Zygmunt, 1998, Zbędni, zniechęceni, odtrąceni - o biednych w zamożnym świecie, Kultura i Społeczeństwo, nr 2.

Dahrendorf Ralf, 1993, Nowoczesny konflikt społeczny. Esej o polityce wolności, tłum. Stefan Bratkowski i in., Czytelnik, Warszawa.

Danecka Marta, 2008, Ubodzy i bezrobotni, w: Maria. Jarosz (red.), Wykluczeni. Wymiar społeczny, materialny $i$ etniczny, ISP PAN Warszawa.

Frączak Piotr, Wygnański Jan Jakub, 2008, Polski model ekonomii spotecznej. Rekomendacje dla rozwoju, FISE, Warszawa.

Giza-Poleszczuk Anna, Hausner Jerzy, 2008, Wprowadzenie - ekonomia społeczna $i$ rozwój, w: Anna Giza-Poleszczuk, Jerzy Hausner (red.), Ekonomia społeczna w Polsce: osiagnięcia, bariery rozwoju $i$ potencjat $w$ świetle badań, Fundacja Inicjatyw Społeczno-Ekonomicznych, Warszawa.

Golinowska Stanisława i in., 2008, Od ubóstwa do wykluczenia społecznego, IPiSS, Warszawa.

Greffe Xavier, 2007, The Role of Social Economy in Local Development, w: Antonella Noya, Emma Clarence (red.), The Social Economy. Building Inclusive Economies, OECD, Paris.

Gumkowska Marta, Herbst Jan, Radecki Przemysław, 2008, Podstawowe fakty o organizacjach pozarzadowych, Raport $z$ badań 2008, Stowarzyszenie Klon/Jawor.

Kaźmierczak Tomasz, 2005, Centra integracji społecznej jako pomyst na przeciwdziatanie wykluczeniu spotecznemu? Refleksje wokót Ustawy o zatrudnieniu socjalnym, „Trzeci Sektor”, nr 2.

Kaźmierczak Tomasz, Rymsza Marek, 2007, Kapitał społeczny. Ekonomia społeczna, ISP Warszawa.

Królikowska Anna, 2005, Finansowanie instytucji ekonomii społecznej, „Trzeci Sektor”, nr 2. 
Leś Ewa (red.), 2007, „Monitoring ustawy z dnia 13 czerwca 2003 r. o zatrudnieniu socjalnym. Badanie efektów reintegracji społecznej i zawodowej", Pracownia Badań Organizacji Non-Profit, Instytut Studiów Politycznych PAN, Warszawa (www.gospodarkaspoleczna.pl/index.php/badaniaarch).

Nałęcz Sławomir (red.), 2008, Gospodarka społeczna w Polsce. Wyniki badań 2005-2007, ISP PAN, Warszawa.

Rechulicz Marcin, 2006, Organizacje pozarządowe - alternatywa dla przedsiębiorczości czy przedsiębiorczość?, „Trzeci Sektor”, nr 7.

Rymsza Marek, 2006, Polityka społeczna a więzi społeczne. Przypadek Trzeciej Rzeczpospolitej, „Societas/Communitas”, nr 1.

Sałustowicz Piotr, 2006, Koncepcje i funkcje ekonomii społecznej, w: Piotr Sałustowicz, Halina Guzowska (red.), Ekonomia społeczna a bezradność społeczna — perspektywy i bariery, Biuro Rzecznika Praw Obywatelskich, Warszawa.

Tarkowska Elżbieta, 2000, Zrozumieć biednego. O dawnej i obecnej biedzie w Polsce, IFiS PAN-Typografika, Warszawa.

Wygnański Jan Jakub, 2008, Przedsiębiorstwo społeczne. Antologia kluczowych tekstów, FISE, Warszawa.

Zalewski Dariusz, 2005, Opieka i pomoc społeczna. Dynamika instytucji, UW, Warszawa.

$*$

Bezrobocie rejestrowane I kwartat 2009, GUS 2009.

Centra Integracji Społecznej i Ośrodki Wspierania Spótdzielni Socjalnych. Instytucje aktywnej integracji społecznej, Ministerstwo Polityki Społecznej, Warszawa 2008.

Informacja o działalności Centrów Integracji Społecznej w latach 2007-2008, MPiPS, 2009. Informacja o działalności Centrów Integracji Społecznej w 2009 roku, MPiPS, 2010.

\section{WORK THERAPY, SELECTED ASPECTS OF THE NEW SOCIAL ECONOMY}

\section{Sum mary}

The article concerns the issue of social economy and social employment as one of its forms. Social employment is represented as a modern method of combating social exclusion. It is part of the principles of an active social policy, based above all on voluntary participation, collaboration and concentrating resources on the support of people fit to work, but engulfed by poverty. The author presents the various forms and functions of social employment, the groups of people who are encompassed by such aid, and the methods of reintegration in the social environment and the job market. Statistical data and the opinions of participants in these courses are used to present the results achieved by the spread of social employment schemes in the past few years.

\section{Key words/słowa kluczowe}

social exclusion / wykluczenie społeczne; poverty / bieda; long-term unemployment / bezrobocie długotrwałe; social economy / ekonomia społeczna; social policy / polityka społeczna; social employment / zatrudnienie socjalne 